\title{
Neonatal glycine encephalopathy
}

INSERM

\section{Source}

INSERM. (1999). Orphanet: an online rare disease and orphan drug data base. Neonatal glycine encephalopathy. ORPHA:289857

Neonatal glycine encephalopathy is a frequent, usually severe form of glycine encephalopathy (GE; see this term) characterized by coma, apnea, hypotonia, seizure and myoclonic jerks in the neonatal period, and subsequent developmental delay. 